Психолого-педагогічні проблеми становлення сучасного фахівця

Випуск 2017

Сергей Радул, Елена Кумпан. Теоретические основы изучения самореализации личности в работах иностранных учёных.

B статье рассмотрены теоретические основы изучения понятия «самореализачия личности». Данное понятие проанализировано на философском, психологическом и педагогическом уровнях в работах иностранных учёных. Сделан вывод, что самореализачия - это стремление к самосовершенствованию личности, которое можно рассматривать как осознанный процесс роста потенцииальных $и$ побудительно-мотивационных сущностных сил человека.

Ключевые слова: самореализация, профессиональное совершенствование, логико-системный анализ, личностные потенциаль, потребности личности.

Serhii Radul, Olena Kumpan. Theoretical background for the study of personal self-fulfillment in the researches of foreign scientists. Theoretical background for the study of term «personal self-fulfillment» has been considered in the article. This term has been analyzed at philosophic, psychological and pedagogical levels in the researches of foreign scientists. The conclusion, that a self-fulfillment - is a strive for a personal selfimprovement that can be considered as a conscious development process of human potential and incentive-motivational entity strengths.

Keywords: self-fulfillment, professional enhancement, logics-system analysis, personal potential, individual's needs.

Стаття надійшла до редакційної колегії 23.05.2017

УДК 378.091.26:004.738.5(61:378.4)

(C) Різник О. І., Пушина О. С., 2017

Різник Ольга Іванівна, Пушина Ольга Сергіївна

Запорізький державний медичний університет

\title{
СПРОБА ВИКОРИСТАННЯ GООGLЕ ФОРМ ДЛЯ ТЕСТУВАННЯ СТУДЕНТІВ В ВИЩОМУ МЕДИЧНОМУ НАВЧАЛЬНОМУ ЗАКЛАДІ
}

Застосування інновачійних технологій в вищих медичних навчальних закладах освіти спрямовано на виховання та розвиток особистості студента, створює нові нормативи творчої та індивідуальної спрямованості діяльності викладача. Проаналізовано використання Google Forms стосовно інформованості про фактори ризику виникнення хвороб системи кровообігу в прочесі інтерактивного навчання студентів. Доведено зручність та ефективність використання Google Forms в вищих медичних закладах освіти. 


\section{Збірник наукових статей}

Ключові слова: інтерактивні технології, інформованість, фактори ризику, студенти медичних вищих, Google Forms.

Проблема, ï̈ зв'язок із важливими науковими чи практичними завданнями. Перебудовчі процеси в Україні обумовили нові тенденції щодо розвитку освіти. 3'явилася нагальна потреба суспільства в творчих, діяльних і обдарованих, інтелектуально i духовно розвинених громадянах. Для того, щоб обдарована молодь повністю розкрила свої здібності, реалізувалася в житті, необхідно створити певні умови у навчальному закладі. Саме під час використання на заняттях сучасних освітніх технологій допомагає студентам повністю розкритися, як творчім особистостям.

Аналіз публікацій (виділення невирішених проблем). Сучасні освітні технології - це система створення і застосування процесів викладання і засвоєння знань, яка враховує основні людські та технічні ресурси цих процесів, їх взаємодію з метою оптимізації всіх форм і методів освіти і виховання. Дана система орієнтована на студента 3 урахуванням його здібностей і можливостей, потреб та інтересів. Для підготовки фахівця, що володіє даними якостями, необхідний новий тип освіти, який вимагає змінам ситуації навчання i педагогічного професіоналізму та відповідає новим умовам [1;2]. Саме в даному контексті розуміння змін, що відбуваються зараз, слід нині розглядати інноваційні моделі освіти і адекватні їм моделі педагогічного професіоналізму. Сьогодні склалися передумови, які зумовили необхідність застосування інноваційних технологій навчання. Ці технології повинні бути мобільними, щоб миттєво реагувати на зміни ситуації на ринку праці і коригувати модель майбутнього спеціаліста; вони повинні забезпечувати індивідуалізацію освітніх програм і шляхів їх засвоєння в залежності від здібностей i інтересів студентів [3; 4]. Застосування інноваційних технологій в вищих медичних навчальних закладах освіти пов'язано з відмовою від відомих штампів, стереотипів в навчанні, виховання та розвитку особистості студента, виходить за рамки діючих нормативів, створює нові нормативи особистісно-творчої, індивідуальної спрямованості діяльності викладача.

Ціль статті - вивчити зручність використання Google Forms для тестування студентів під час практичних занять на кафедрі.

Виклад основного матеріалу, обгрунтування результатів дослідження. Нами було опитано 77 особи, студенти 1 курсу Запорізького державного медичного університету, з них 60,3 \% жінки, $39,7 \%$ чоловіки, середній вік - 19,4 років, в Google Forms стосовно їх інформованості про фактори ризику серцево-судинних захворювань. 
Студенти мали змогу пройти опитування під час занять, 3 власного смартфона, планшета, комп'ютера чи скористатися комп'ютерним класом. Після отримання посилання на Google Forms, он-лайн відповіді на питання стосовно інформованості про фактори ризику хвороб системи кровообігу надавалися он-лайн, в режимі реального часу. Одразу після закінчення анкетування, студент мав можливість здійснити самоконтроль та перевірити свої знання, дізнатися правильну відповідь. Після кожного опитування, програма Google самостійно вносить дані до таблиць Excel, що підвищує ефективність процесів статистичної обробки та аналізу відповідей. Одразу після закінчення анкетування із студентами були проведені бесіди з профілактики хвороб системи кровообігу із більш детальним аналізом тих питань, на які більше половини опитуваних дали неправильні відповіді. Здоров'я кожної людини на 50\% залежить від способу життя, саме тому модифікація поведінкових факторів ризику, перш за все відмова від тютюнопаління, нездорового харчування, гіподинамії та надмірного вживання алкоголю здатна попередити виникнення захворювань та їх прогресування, передчасну смертність та інвалідність [5]. Наша країна зайняла активну позицію щодо імплементації стратегії Всесвітньої організації охорони здоров'я (ВОО3) 3 профілактики неінфекційних захворювань (НI3), в якої передбачено програму профілактичних заходів як на загальнодержавному, так i на індивідуальному рівнях. На національному рівні були досягнені певні здобутки (прийняття закону про заборону паління в громадських місцях, збільшення акцизів на тютюн, прийняття національної стратегії 3 оздоровчої рухової активності) [6], але на індивідуальному рівні заходи із зниження тягаря НI3, на жаль, залишаються малоефективними та високо затратними, що вірогідно зв'язано із низьким рівнем інформованості та мотивації населення щодо здорового способу життя [7]. У всесвітній історії існує чимало прикладів впливу інформаційно-комунікаційних технологій на показники здоров'я населення позитивним чином. Досить згадати надзвичайний досвід Фінляндії та проекту «Північна Карелія», завдяки якому збільшилася тривалість життя та зменшилась смертність від серцево-судинних захворювань, також досить ефективну інформаційну компанію у Чехї̈ «Відмовся і виграєш», завдяки якої 25\% учасників кинула палити. Зараз, із прогресом у електронних i мобільних технологіях, з'явились нові можливості інформування та опитування, 3 можливістю отримати зворотній зв'язок. Сформувалося суспільство нового типу, що засноване на знаннях -K-суспільство (від knowledgeзнання) [8]. В свою чергу, населення поділяється на «цифрових аборигенів», що були народжені після 1980 р., і до яких належать наші студенти, та «цифрових іммігрантів» - 40-річних осіб та старше [9]. 


\section{Збірник наукових статей}

Саме через ці зміни у суспільстві змінюється й система інформування та навчання студентів медичних вищих. Серед опитуваних - 95\% відмітили, що користуватися Google Forms зручно і легко, а 97\% вважають Google Forms кращою альтернативою звичним тестуванням та анкетуванням на паперових носіях чи в системі RATOS. 70\% студентів вважають за потрібне після заповнення Google Forms отримувати персональну статистику на свою поштову скриньку для проведення самоконтролю i більш кращого вивчення та запам'ятовування матеріалу.

Висновки, перспективи. 1. Інтерактивні технології $\epsilon$ важливим складником особистісно-зорієнтованого навчання в вищому медичному закладі освіти. 2. Google Forms дозволяє слідкувати за відповідями студентів в режимі реального часу і аналізувати дані в Google таблицях або інших додатках. 3. Використання Google Forms в вищих медичних закладах освіти має високу економічну ефективність в зв'язку зі зниженням затрат на паперові носії, а також час викладача на їх обробку, перевірку та висновки.

\section{Література}

1. Демчук М. И. Высшая школа в стратегии инновационного развития республики Беларусь / М. И. Демчук. - Мн. : «РИВШ», 2006. -299 c.

2. Новые педагогические и информационные технологии в системе образования / Под ред. Полат Е. С. - М. : Владос, 2002. $183 \mathrm{c}$.

3. Суворова Н. «Интерактивное обучение - Новые подходы» / Н. Суворова. - М., 2005. - 125 с.

4. Чернилевский Д. В. Инновационные технологии и дидактические средства современного профессионального образования / Д. В. Чернилевский, В. Б. Моисеев. - М. : МГИЦ, 2002. $150 \mathrm{c}$.

5. Global status report on noncommunicable diseases 2010 / WHO. Geneva : WHO, $2011-162$ p.

6. Пузанова О. Г. Інформаційні технології профілактики серцево-судинних захворювань у первинній ланці охорони здоров'я у первинній ланці охорони здоров'я: дієвість консультування щодо фізичної активності та харчування / О. Г. Пузанова // Східноєвропейський журнал громадського здоров'я. - 2011. - № 2. C. 68-73.

7. Лашкул 3. В. Концептуальні підходи до профілактики артеріальної гіпертензії в умовах реформування охорони здоров'я / 3. В. Лашкул // Український медичний часопис. - 2014. - № 6 (104). C. 54-60. 
8. Юрьева Л. Н. Формирование киберкультуры: от клинописи к Интернету / Л. Н. Юрьева // Новости медицины и фармации в Украине. - 2015. - № 15 (558). - C. 20-21.

9. Impact of mHealth chronic disease management on treatment adherence and patient outcomes : a systematic review [Online resource] / S. Hamine, E. Gerth Guyette, D. Faulx, B. B. Green, A. Ginsburg // Journal of Medical Internet Research. - 2015. - Vol. 17 (2). - Access mode : https://www.ncbi.nlm.nih.gov/pmc/articles/PMC4376208/.

\section{Ольга Резник, Ольга Пушина. Попытка использования} Google форм для тестирования студентов в высшем медицинском учебном заведении

Применение инновационных технологий в высших медицинских учебных заведениях направлено на воспитание и развитие личности студента, создает новые нормативы творческой и индивидуальной направленности деятельности преподавателя. Проанализировано использование Google Forms относительно информированности о факторах риска возникновения болезней системы кровообращения в процессе интерактивного обучения студентов. Доказано удобство и эффективность использования Google Forms в высших медицинских учебных заведениях.

Ключевые слова: интерактивные технологии, информированность, факторы риска, студенты медицинских высших, Google Forms.

Olga Ryznik, Olga Pushina. An attempt to use Google Forms for testing of students in higher medical institution.

The innovative technologies are used in higher medical educational establishments with an aim to breed and develop student's personality, to make new standards of creative and individual direction of teacher's activity. The use of Google Forms concerning awareness of students about risk factors of cardiovascular diseases while process of interactive education was studied. The convenience and effectiveness of use of Google Forms in higher medical institutions is proved.

Keywords: interactive technologies, awareness, risk factors, students of higher medical institutions, Google Forms.

Стаття надійшла до редакційної колегії 29.05.2017 